\title{
Absence of effect of LH-RH on progesterone production by human luteal cells in vitro
}

\author{
G. J. S. Tan and J. S. G. Biggs \\ Department of Obstetrics and Gynaecology, University of Queensland, Royal Brisbane Hospital, \\ Brisbane 4029, Australia
}

Summary. In acute incubation ( $3 \mathrm{~h}$ ) LH-RH, at concentrations of $10^{1}-10^{6} \mathrm{pg} / \mathrm{ml}$, failed to affect either basal or hCG-induced progesterone production by human luteal cells, from tissue taken in the early, mid or late luteal phase.

\section{Introduction}

The physiological role of luteinizing hormone-releasing hormone (LH-RH) in mediating the secretion of gonadotrophins is well established. However, administration of large doses of LH-RH produces a paradoxical anti-fertility effect. Thus, in women, agonists of LH-RH have been shown to inhibit ovulation (Nillius, Bergquist \& Wide, 1978) and interfere with corpus luteum function (Casper \& Yen, 1979). The luteolytic effect of LH-RH raises the possibility of an interceptive role of this hormone in fertility control. There is little information on the effect of LH-RH on the human corpus luteum although in-vivo studies suggest that the corpus luteum is one of the sites of LH-RH action (Casper \& Yen, 1979). The present in-vitro study examines the influence of LH-RH on human luteal steroidogenesis in short-term incubation.

\section{Materials and Methods}

Corpora lutea (CL) were obtained from non-pregnant women with regular cycles, aged between 25 and 45 years, who were undergoing ovarian resection for various gynaecological reasons unrelated to the present study. The ages of the CL were determined from the date of the last menstrual period and endometrial histology, and classified as early (Days 14-18), mid (Days 19-23) or late (Day 24 onwards) luteal phase.

Isolated luteal cells were prepared as described previously (Tan, Tweedale \& Biggs, 1982). Luteal cells were incubated with various concentrations of $\mathrm{LH}-\mathrm{RH}\left(10^{1}-10^{6} \mathrm{pg} / \mathrm{ml}\right)$ in the presence or absence of hCG (10 i.u./ml). Synthetic LH-RH (Gonadorelin) was supplied by Ayerst Laboratories Pty Ltd, Parramatta, New South Wales, Australia. The incubations were terminated by freezing the samples in solid $\mathrm{CO}_{2}$; samples were then stored at $-20^{\circ} \mathrm{C}$ until assayed.

Progesterone was assayed by the method of Abraham, Swerdloff, Tulchinsky \& Odell (1971) as previously reported (Tan et al., 1982). Production of progesterone was all normalized to $10^{5}$ cells/incubation, and the data were statistically analysed by paired comparison using Student's $t$ test. $P$ values $>0.01$ were not considered significant. 


\section{Results}

Significant basal progesterone production occurred in all except one CL during $3 \mathrm{~h}$ of incubation (Table 1). Addition of a maximally stimulating dose of hCG $(10 \mathrm{i} . \mathrm{u} . / \mathrm{ml})$ enhanced the production of progesterone by all luteal cells. However, neither basal nor hCG-induced progesterone production was affected by LH-RH.

Table 1. Effect of LH-RH on progesterone production by human luteal cells at early, mid or late luteal phase of the cycle

\begin{tabular}{|c|c|c|c|c|}
\hline & \multicolumn{4}{|c|}{ Progesterone content (ng/10 $10^{5}$ cells) } \\
\hline & $\begin{array}{c}\text { Exp. } 1 \\
\text { (late) }\end{array}$ & $\begin{array}{l}\text { Exp. } 2 \\
\text { (mid) }\end{array}$ & $\begin{array}{c}\text { Exp. } 3 \\
\text { (late) }\end{array}$ & $\begin{array}{l}\text { Exp. } 4 \\
\text { (early) }\end{array}$ \\
\hline Unincubated control & $5.7 \pm 0.4$ & $3 \cdot 5 \pm 0 \cdot 3$ & $1.9 \pm 0.1$ & $9.5 \pm 0.5$ \\
\hline Incubated control & $18 \cdot 3 \pm 1 \cdot 2^{b}$ & $6 \cdot 3 \pm 0.5^{b}$ & $2 \cdot 3 \pm 0 \cdot 2$ & $11 \cdot 3 \pm 0.6^{a}$ \\
\hline \multicolumn{5}{|l|}{ LH-RH (pg/ml) } \\
\hline $\begin{array}{l}10^{1} \\
10^{2}\end{array}$ & $\begin{array}{c}17.5 \pm 0.6 \\
-\end{array}$ & $\begin{array}{l}5.8 \pm 0.2 \\
5.6+0.4\end{array}$ & $2 \cdot 7 \pm 0.4$ & $\begin{array}{l}10.9 \pm 0.5 \\
10.9+0.6\end{array}$ \\
\hline $10^{3}$ & $16.9 \pm 1.6$ & $5 \cdot 5 \pm 0 \cdot 3$ & $2 \cdot 7 \pm 0.2$ & - \\
\hline $10^{4}$ & - & $5 \cdot 8 \pm 0 \cdot 2$ & - & $11.0 \pm 0.5$ \\
\hline $10^{5}$ & $16 \cdot 8 \pm 1 \cdot 1$ & $5 \cdot 7 \pm 0 \cdot 4$ & $2 \cdot 5 \pm 0 \cdot 2$ & - \\
\hline $10^{6}$ & 二 & 二 & $2 \cdot 7 \pm 0.2$ & $10.9 \pm 0.5$ \\
\hline hCG $(10$ i.u. $/ \mathrm{ml})$ & $51 \cdot 8 \pm 3 \cdot 2^{c}$ & $66 \cdot 8 \pm 3 \cdot 3^{c}$ & $19 \cdot 9 \pm 1 \cdot 4^{c}$ & $41 \cdot 5 \pm 1 \cdot 1^{\circ}$ \\
\hline \multicolumn{5}{|l|}{$\mathrm{hCG}+\mathrm{LH}-\mathrm{RH}(\mathrm{pg} / \mathrm{ml})$} \\
\hline $10^{1}$ & $49 \cdot 6 \pm 2 \cdot 8$ & $58 \cdot 3 \pm 4 \cdot 4$ & $19 \cdot 8 \pm 1 \cdot 1$ & $38.8 \pm 1.9$ \\
\hline $10^{2}$ & - & $60 \cdot 0 \pm 3 \cdot 4$ & - & $38 \cdot 1 \pm 1 \cdot 9$ \\
\hline $10^{3}$ & $51 \cdot 5 \pm 4 \cdot 2$ & $59.6 \pm 3.8$ & $20 \cdot 1 \pm 1 \cdot 1$ & 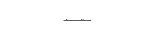 \\
\hline $10^{4}$ & - & $62.2 \pm 2.6$ & 二 & $38.9 \pm 1.4$ \\
\hline $10^{5}$ & $50 \cdot 1 \pm 3.9$ & $58.5 \pm 5.4$ & $20 \cdot 1 \pm 1.7$ & - \\
\hline $10^{6}$ & $一$ & - & $18.6 \pm 0.9$ & $38 \cdot 0 \pm 2 \cdot 6$ \\
\hline
\end{tabular}

Luteal cells were incubated for $3 \mathrm{~h}$ with various test substances in Ham's F10 medium in $95 \%$ $\mathrm{O}_{2}-5 \% \mathrm{CO}_{2}$ at $37^{\circ} \mathrm{C}$. Values represent the mean \pm s.d. of quadruplicate incubates.

a $P<0.01$; $P<0.001$, compared with unincubated control; ${ }^{c} P<0.001$, compared with incubated control (Student's $t$ test).

\section{Discussion}

These results show a lack of effect of LH-RH on human luteal cell steroidogenesis in vitro. Neither basal nor hCG-induced progesterone production was affected by a wide range of LH-RH concentrations in culture medium. At a concentration of $10^{6} \mathrm{pg} / \mathrm{ml}, \mathrm{LH}-\mathrm{RH}$ also failed to influence the response of human luteal cells to submaximal stimulatory doses of hCG (unpublished observation). These findings are in agreement with those of studies with dispersed luteal cells from rhesus monkeys in which D-Trp-6-LH-RH failed to affect progesterone production in short-term culture (Asch, Smith, Almirez \& Schally, 1980). However, in non-primate species such as the rat, agonists of LH-RH have been repeatedly shown to inhibit the production of progesterone by luteal cells in acute incubation (Clayton, Harwood \& Catt, 1979; Behrman, Preston \& Hall, 1980). Species differences may partly explain the negative findings in the present study.

The work on effects of LH-RH on luteal function in women has been equivocal. While induction of luteolysis with an LH-RH agonist has been described (Casper \& Yen, 1979) both normal and even prolonged luteal phases have been reported (Bergquist, Nillius \& Wide, 1980). A determining factor in the type of ovarian response in vivo appears to be the stage of luteal phase at which LH-RH is given (Lemay, Labrie, Belanger \& Raynaud, 1979) although the mode of administration (e.g. continuous or pulsatile) may be important. 
Several mechanisms have been postulated for the luteolytic action of LH-RH on the human ovary. A direct effect of LH-RH on the CL has been proposed by Casper \& Yen (1979). Extragonadal action by the desensitizing effect of elevated gonadotrophins on ovarian LH receptors (Lemay et al., 1979) or decreased pituitary sensitivity (Bergquist et al., 1979) have also been suggested. Although the negative findings in the present study would support an extragonadal effect of LH-RH in women, further study is needed to support this hypothesis.

This study was supported by a grant to J.S.G.B. from the National Health and Medical Research Council, Australia G.J.S.T. was in receipt of a scholarship from the University of Queensland. We thank Miss R. Tweedale for technical assistance.

\section{References}

Abraham, G.E., Swerdlofi, R., Tulchinsky, D. \& Odell, W.D. (1971) Radioimmunoassay of plasma progesterone. J. clin. Endocr. Metab. 32, 619-624.

Asch, R.H., Smith, C.G., Almirez, R.G. \& Schally, A.V. (1980) Absence of in vitro effects of luteinizing hormone releasing hormone agonists (D-Trp-6LHRH) on progesterone (P) production by rhesus monkey corpora lutea. Proc. 27th A. Meeting Soc. Gynec. Invest., Denver p. 223, Abstr.

Behrman, H.R., Preston, S.L. \& Hall, A.K. (1980) Cellular mechanism of the antigonadotropic action of luteinizing hormone-releasing hormone in the corpus luteum. Endocrinology 107, 656-664.

Bergquist, C., Nillius, S.J. \& Wide, L. (1979) Reduced gonadotropin secretion in postmenopausal women during treatment with a stimulatory LRH analogue. J. clin. Endocr. Metab. 49, 472-475.

Bergquist, C., Nillius, S.J. \& Wide, L. (1980) Effects of a luteinizing hormone-releasing hormone agonist on luteal function in women. Contraception 22, 287-293.
Casper, R.F. \& Yen, S.C.C. (1979) Induction of luteolysis in the human with a long-acting analogue of luteinizing hormone-releasing factor. Science, N.Y. 205, 408-410.

Clayton, R.N., Harwood, J.P. \& Catt, K.J. (1979) Gonadotropin-releasing hormone analogue binds to luteal cells and inhibits progesterone production. Nature, Lond. 282, 90-92.

Lemay, A., Labrie, F., Relanger, A. \& Raynaud, J.P. (1979) Luteolytic effect of intranasal administration of [D-Ser (TBU) ${ }^{6}$,DES-GLY-NH ${ }_{2}{ }^{10}$-luteinizing hormone-releasing hormone ethylamide in normal women. Fert. Steril. 32, 646-651.

Nillius, S.J., Bergquist, C. \& Wide, L. (1978) Inhibition of ovulation in women by chronic treatment with a stimulatory LRH analogue-a new approach to birth control? Contraception 17, 538-545.

Tan, G.J.S., Tweedale, R. \& Biggs, J.S.G. (1982) Oxytocin may play a role in the control of the human corpus luteum. J. Endocr. 95, 65-70.

Received 10 August 1982 